\title{
The use of gene technologies in the genomic- index assessment of producers of Canadian breeding
}

\author{
Nurmagomed Bukarov ${ }^{1}$, Vasily Zakharov ${ }^{2}$, Shamsutdin Hashegulgov ${ }^{3}$, Ibragim Taov $^{4}$, and \\ Tsray Kagermazov ${ }^{4, *}$ \\ ${ }^{1}$ JSC "Moskovskoye" breeding enterprise, str. Soyedinitelnaya, 7, 142403 Noginsk, Moscow region, \\ Russia \\ ${ }^{2}$ Federal State Budgetary Scientific Institution "All-Russian Research Institute of Breeding", str. \\ Lenina, 13, Moscow Region, 141212 Pushkino, Lesnye Polyany, Russia \\ ${ }^{3}$ FSBEI HE "Ingush State University", I.B. Zyazikova av., 7, 366700 Magas, Russia \\ ${ }^{4}$ Kabardino-Balkarian State Agricultural University named after V.M.Kokov, Lenin Avenue, 1V, 360030 \\ Nalchik, Russia
}

\begin{abstract}
The article provides an assessment of the use of gene technologies in the genomic-index assessment of producers in the conditions of farms in the Moscow region, which allows to provide dairy farming with high-quality breeding material. Genomic index assessment accelerates the breeding goal achievement process. It contributed to an increase in the productivity of cattle, an increase in the profitability of cattle breeding, which allows to reduce the time for creating breeding herds of dairy cattle by 2 times. Of the 15 bulls, $10(67 \%)$ were evaluated by the A1-A3 breeding categories. Two bulls were categorized as neutral. The bull Ecuador received the A2B1 breeding categories. The daughters of this bull are fat and milk enhancers, which is $4.46 \%$, with a milk yield of 12432 $\mathrm{kg}$ of milk.
\end{abstract}

\section{Introduction}

Genomic scanning methods allow to determine the origin of animals, the genetic potential of productivity, as well as to accelerate the creation of breeding herds. Genomic assessment is a powerful tool for use in breeding programs. Marker breeding increases the importance of all breeding procedures, thereby accelerating the genetic improvement of herds in terms of productive qualities. For instance, this method is already being used to assess the fertility of bulls (DPR, the pregnancy index of the daughters of a bull) and the resistance of animals to diseases.

Genomic technologies may significantly improve breeding efficiency and eliminate the disadvantages of the livestock breeding traditional methods.

Pursuant to the research in the Russian Federation and abroad, it should be noted that the biotechnological innovations allow to create new genotypes of livestock exceeding the original animals by $30-40 \%[1,2,5,6-10]$.

*Corresponding author: laura07@yandex.ru 
Pursuant to the regional concept (Program for the improvement of dairy cattle of the Moscow region for the period until 2022), by 2023, the average milk yield per forage cow will reach $7300-7500 \mathrm{~kg}$ in the farms of the Moscow region, with a fat content of $4.10 \%$ and a protein content of $3.30-3.35 \%$. More than $40 \%$ of animals should be breeding, with a cow milk yield of $10,000 \mathrm{~kg}$ or more.

The accelerated formation of highly productive breeding herds will be ensured using the breeding genetic resources of the countries of the leading market suppliers.

In this regard, we are interested in the adaptive potential of cattle of Canadian origin. In the Russian Federation, there is still insufficient data on the suitability for use of livestock of Canadian origin in milk production. This determined the need to import Canadian cattle into our country and assess the prospects for this decision.

The paper is aimed is to examine the genome-valued seed bulls to study their productive qualities in the conditions of farms in the Moscow Region and to provide dairy farming with high-quality breeding material, which allows to reduce the time for creating pedigree herds of dairy cattle by 2 times, while increasing the profitability of farmed livestock.

\section{Material and methods}

The research material is data on the daughters of 15 genome evaluated bulls of Canadian origin. Genomic assessment was performed for 2 breeding indices Pro\$ (economic assessment) and GLPI (indicator of genomic assessment of lifelong productivity). The value of LPI - consists of 4 important components: indicators of milk production, durability of cows, health and fertility. Herewith, the value of the economic index Pro\$ undergoes an annual update. It is associated with changes in milk prices in Canada, as well as an increase in the cost of livestock production. It is noted that the values of the quantities obtained by the Pro\$ index have significantly expanded the interval of their distribution. In highly productive animals, an increase in the value of the index is observed, while the indices with low productivity indicators drop an order of magnitude lower. In the Holstein breed bred in Canada, the average growth of the Pro\$ index at the beginning of 2019 amounted to USD 371 and reached USD 670. Pro\$ index has been introduced into practice since August 2015 $[3,4]$. The second index was introduced due to the need to improve the selection accuracy and satisfy the desire of breeders to have a reliable breeding tool capable of improving the entire set of specified breeding indicators. Both indices have found practical use.

The research was performed in the breeding farms of the Moscow region. The information database on the assessment of dairy cattle in the Moscow region (Regional Breeding Information Center "Mospleminform") was used as of 1.05.2019. We also used information from the catalogs of breeding bulls of JSC "Moskovskoye" for breeding, published in 2018-2020. In JSC "Moskovskoe", high requirements are imposed on Holstein bulls purchased for the breeding enterprise.

The selection of bulls born in 2011-2012 at the age of 7 months and older was performed pursuant to the genomic assessment. We selected animals with good health, development, conformation, milky body type, strong limbs, developed genitals.

In genetic terms, the elimination of bulls-carriers of genes, which in a homozygous state lead to the death of embryos and fetuses, was performed. These are primarily BLAD, CVM, BY, HCD mutations, HH1-HH5 haplotypes. The work performed in this direction to date has made it possible to identify more than 10 haplotypes that negatively affect fertility and remove them from breeding use. 


\section{Results and discussion}

Pursuant to the results of the analysis of the data in Table 1, it follows that representatives of two lines were selected as fathers $(n=15)$. Table 1 presents data on the prediction of the potential of young bulls.

Table 1. Genomic forecast of productivity indicators for young Holstein bulls of Canadian origin.

\begin{tabular}{|l|c|c|c|c|c|c|c|}
\hline Bull, original no. & Pro\$ & GLPI & $\begin{array}{c}\text { Milk, } \\
\mathbf{k g}\end{array}$ & $\begin{array}{c}\text { Fat, } \\
\mathbf{\%}\end{array}$ & $\begin{array}{c}\text { Protein, } \\
\mathbf{\%}\end{array}$ & Father & Line \\
\hline HOCANM106739661 & 846 & 2400 & 1880 & 0.15 & 0.06 & C. GarrettET52805710 & UI \\
\hline HOCANM107359022 & 742 & 2416 & 1777 & 0.37 & 0.13 & F. Snowman 388965513 & UI \\
\hline HOCANM107522503 & 891 & 2524 & 1143 & 0.24 & 0.14 & V-E-D Sudan ET62768990 & RS \\
\hline HOCANM107870105 & 1016 & 2637 & 1814 & -0.12 & 0.12 & D. Mayfield ET69473980 & RS \\
\hline HOCANM11218165 & 674 & 2345 & 1686 & 0.15 & 0.01 & E. Bakon ET136800233 & UI \\
\hline HOCANM107359094 & 762 & 2403 & 2218 & 0.00 & -0.01 & F.G. Snowman 388965513 & UI \\
\hline HOCANM107870103 & 1407 & 2679 & 1897 & 0.09 & 0.11 & M.DSI Mogul & UI \\
\hline HOCANM11230463 & 547 & 2341 & 1771 & 0.11 & 0.16 & L. Oman-OmanET135746776 & UI \\
\hline HOCANM11492044 & 562 & 2303 & 1473 & 0.24 & 0.19 & D. Phoenix 588ET66636724 & RS \\
\hline HOCANM107870111 & 1176 & 2554 & 1698 & 0.16 & 0.21 & D. Phoenix 588ET666636724 & RS \\
\hline HOCANM11230547 & 1020 & 2533 & 879 & 0.36 & 0.23 & D. BukemET66636657 & RS \\
\hline HOCANM107522499 & 1019 & 2571 & 1586 & 0.35 & 0.14 & V-E-D Sudan ET62768990 & RS \\
\hline HOCANM11203408 & 563 & 2476 & 1570 & -0.08 & 0.10 & F.G. Snowman 388965513 & UI \\
\hline HOCANM107359084 & 762 & 2403 & 2311 & 0.00 & 0.00 & F.G. Snowman 388965513 & UI \\
\hline HOCANM11492002 & 79 & 2119 & 2050 & -0.08 & -0.04 & V.Explode138905680 & UI \\
\hline
\end{tabular}

Bulls are mostly represented by the Wes Ideal line 933122 (UI; $n=9$ ), to a lesser extent the Reflection Sovering 198998 (RS, $n=6$ ). Bulls-producers were evaluated pursuant to 8 indicators of productive qualities. The characteristics of the bull-producer begins with the origin, for instance, based on the designation of the breed-HO-Holstein-Holstein, CANCanada, M-bull belonging to JSC "Moskovskoe" for breeding work and its number. This is followed by the projected estimates of economic indicators based on the genomic forecast of lifetime productivity, followed by the forecast for milk yield, as well as indicators of the content of fat and protein in milk.

For those wishing to learn the details of the genomic forecast for each of the young bulls delivered to the Russian Federation, there are detailed information on the Canadian Dairy Network website. Bull numbers are mostly 9-digit, but there are also 8-digit numbers. The latter are included in the list of genome-valued young bulls. By typing 8-digit numbers in the Query search engine, one can access all the information about the parameters of interest to the manager-livestock breeder.

Table 1 shows mainly the data on the productivity potential of bulls. Herewith, other parameters were not used, for example, the productivity of mothers of bulls, indicators of conformation and reproduction. All these and some other parameters were obtained by genomic scanning and are used in breeding work. It should be noted that 9 out of 15 bulls were obtained by embryo transfer.

Table 2 shows the performance indicators of the daughters of bulls. In it, in 8 columns, the results of evaluating bulls by the quality of offspring are presented. 
Table 2. Performance indicators of the daughters of 15 genome-rated sire sires.

\begin{tabular}{|c|c|c|c|c|c|c|c|c|}
\hline \multirow{2}{*}{ Bull } & \multicolumn{4}{|c|}{ Productivity indicators } & \multicolumn{2}{c|}{ Daughters of the same age } \\
\cline { 2 - 9 } & $\begin{array}{c}\text { Milk yield of } \\
\text { daughters } \\
\text { n kg }\end{array}$ & $\begin{array}{c}\text { Fat, } \\
\mathbf{\%}\end{array}$ & $\begin{array}{c}\text { Protein, } \\
\mathbf{\%}\end{array}$ & $\begin{array}{c}\text { Breeding } \\
\text { category }\end{array}$ & $\begin{array}{c}\text { Milk, } \\
\text { kg }\end{array}$ & $\begin{array}{c}\text { Fat, } \\
\mathbf{\%}\end{array}$ & $\begin{array}{c}\text { Protein, } \\
\%\end{array}$ \\
\hline $\begin{array}{c}\text { K. Lotong } \\
\text { M106739661 }\end{array}$ & 295 & 12139 & 4.28 & 3.23 & B1 & +52 & +0.05 & +0.01 \\
\hline Colin M107359022 & 189 & 12122 & 4.27 & 3.36 & A3B3 & +83 & +0.02 & +0.02 \\
\hline Crete M107522503 & 81 & 12089 & 4.05 & 3.29 & A3 & +123 & 0.00 & +0.04 \\
\hline $\begin{array}{c}\text { Lightup } \\
\text { M107870105 }\end{array}$ & 30 & 9499 & 4.22 & 3.37 & H & +33 & -0.24 & +0.01 \\
\hline Lifey M11218165 & 100 & 11761 & 4.34 & 3.31 & A3 & +136 & -0.04 & -0.02 \\
\hline Loni M 107359094 & 80 & 12131 & 4.17 & 3.31 & A1 & +534 & -0.01 & +0.06 \\
\hline Movi M107870103 & 33 & 12416 & 4.22 & 3.24 & A1 & +311 & -0.04 & 0.00 \\
\hline $\begin{array}{c}\text { O-Lexus } \\
\text { M11230463 }\end{array}$ & 62 & 12026 & 4.25 & 3.26 & A3 & +103 & 0.00 & +0.05 \\
\hline Poncho M11492044 & 53 & 131364 & 4.10 & 3.28 & A1 & +580 & -0.01 & +0.01 \\
\hline Poirot M107870111 & 21 & 12001 & 4.24 & 3.40 & H. & -62 & 0.00 & +0.06 \\
\hline Real M11230547 & 74 & 11038 & 4.05 & 3.26 & B2 & +2 & +0.03 & 0.04 \\
\hline Suban M107522499 & 111 & 11595 & 4.09 & 3.38 & B1 & +29 & +0.05 & +0.07 \\
\hline Flevo M11203408 & 87 & 12084 & 4.15 & 3.36 & A1 & +260 & -0.06 & +0.01 \\
\hline $\begin{array}{c}\text { Ecuador } \\
\text { M107359084 }\end{array}$ & 32 & 12432 & 4.46 & 3.17 & A2B1 & +262 & +0.06 & -006 \\
\hline Exo M11492002 & 37 & 12281 & 3.99 & 3.40 & A1 & +521 & -0.04 & -0.02 \\
\hline
\end{tabular}

Herewith, 10 out of 15 bulls (67\%) were assessed by the breeding categories A1-A3. Two bulls were categorized as neutral. Note also that the Ecuador bull received breeding categories A2B1. The daughters of this bull improve the fat-milk content, which is $4.46 \%$, with a milk yield of $12432 \mathrm{~kg}$ of milk. These parameters almost reach the final standards: a milk yield of more than $10,000 \mathrm{~kg}$, with a fat content of $4.5 \%$ and a protein-milk content of $3.45 \%$. Thus, the assessments of the daughters of Canadian bulls showed that a significant increase in productivity and profitability of production was obtained in farms raising dairy cattle from cows. Milk yield exceeded the level of $10,000 \mathrm{~kg}$ of milk.

\section{Conclusions}

Bulls of the Holstein cattle breed of Canadian origin significantly increase the productive qualities of the bred cattle in the conditions of our country, the cattle has a good adaptive potential and is recommended for use in breeding work.

\section{References}

1. N. Yanchukov, Thesis ... of doctor in agricultural sciences, 345 (2011)

2. Dairy and beef cattle breeding, 8, 6 (2013)

3. L. Beavers, B. V. Doormaal, Canadian Dairy Network-Information (2015)

4. B. V. Doormaal, Canadian Dairy Network-Information (2019)

5. Janchukov, Elite Genetics. Catalogue of Dairy sires, 24 (2020) 
6. T. T. Tarchokov, IOP Conference Series: Earth and Environmental Science, 341(1), 012047 (2019)

7. A. A. Mishkhozhev, Animal breeding, 11, 24 (2017)

8. A. A. Zhilyaev, Animal breeding, 9, 8 (2020)

9. T. T. Tarchokov, Animal breeding, 5, 27 (1996)

10. M. O. Baytaev, Agrarian Russia, 1, 28 (2013) 